\title{
Clinico-pathological analysis of renal cell carcinoma demonstrates decreasing tumour grade over a 17 -year period
}

\author{
Gregory J. Nason, MD; Barry B. McGuire, MD; Michael E. Kelly, MD; Theodore M. Murphy, MD; \\ Aisling T. Looney, MD; Damien P. Byrne, MD; David W. Mulvin, MD; David J. Galvin, MD; David M. Quinlan, MD; \\ Gerald M. Lennon, MD
}

Department of Urology, St Vincent's University Hospital, Dublin 4, Ireland

See related article on page 133.

Cite as: Can Urol Assoc J 2014;8(3-4):125-32. http://dx.doi.org/10.5489/cuaj.1721

Published online April 14, 2014.

\section{Abstract}

Introduction: Renal cell carcinoma (RCC) represents about 3\% of adult malignancies in Ireland. Worldwide there is a reported increasing incidence and recent studies report a stage migration towards smaller tumours. We assess the clinico-pathological features and survival of patients with RCC in a surgically treated cohort.

Methods: A retrospective analysis of all nephrectomies carried out between 1995 and 2012 was carried out in an Irish tertiary referral university hospital. Data recorded included patient demographics, size of tumour, tumour-node-metastasis (TNM) classification, operative details and final pathology. The data were divided into 3 equal consecutive time periods for comparison purposes: Group 1 (1995-2000), Group 2 (2001-2006) and Group 3 (2007-2012). Survival data were verified with the National Cancer Registry of Ireland.

Results: In total, 507 patients underwent nephrectomies in the study period. The median tumour size was $5.8 \mathrm{~cm}$ (range: 1.2$20 \mathrm{~cm}$ ) and there was no statistical reduction in size observed over time $(p=0.477)$. A total of $142(28 \%)$ RCCs were classified as pT1a, 111 (21.9\%) were pT1b, 67 (13.2\%) were pT2, $103(20.3 \%)$ were pT3a, $75(14.8 \%)$ were $\mathrm{pT} 3 \mathrm{~b}$ and $9(1.8 \%)$ were $\mathrm{pT} 4$. There was no statistical T-stage migration observed $(p=0.213)$. There was a significant grade reduction over time $(p=0.017)$. There was significant differences noted in overall survival between the T-stages $(p<0.001)$, nuclear grades $(p<0.001)$ and histological subtypes $(p=0.022)$.

Conclusion: There was a rising incidence in the number of nephrectomies over the study period. Despite previous reports, a stage migration was not evident; however, a grade reduction was apparent in this Irish surgical series. We can demonstrate that tumour stage, nuclear grade and histological subtype are significant prognosticators of relative survival in RCC.

\section{Introduction}

Renal cell carcinoma (RCC) is the 12th most common cancer in Ireland, accounting for about 3\% of adult malignancies; the median patient age at diagnosis is $65 .{ }^{1}$ There has been an increasing incidence of RCC reported internationally, in part due to the increase in incidentally diagnosed $\mathrm{RCC}^{2,3}$ as a result of the widespread use and accuracy of modern imaging techniques, such as computed tomography and magnetic resonance imaging. ${ }^{4,5}$

Tumour-node-metastasis (TNM) staging, as well as pathological nuclear (Fuhrman) grading system, has been identified as a reliable and accurate prognosticator in RCC. ${ }^{6-8}$ There have been reports of a shift towards smaller renal tumours with an associated downwards stage migration, ${ }^{9-11}$ with an associated improved cancer-specific survival. ${ }^{12}$ This stage migration towards smaller lower stage tumours, however, was not observed in an Australian series; an upward histological migration was demonstrated. ${ }^{13}$

We assess the clinico-pathological features and survival of patients with RCC in an Irish surgical cohort. Furthermore we evaluate whether a stage migration has developed in our series over the study period.

\section{Methods}

A retrospective review of all nephrectomies (radical and partial) performed in a single urology unit from 1995 to 2012 was conducted. Data recorded included patient demographics, size of tumour, TNM classification (adjusted according to the American Joint Committee on Cancer [AJCC] 2010 guidelines), operative details and final pathology. All specimens were analyzed in the same histopathology department by at least 2 consultant histopathologists. All oncology cases were discussed preoperatively and postoperatively at the departmental multidisciplinary (urology, radiology, histopathology, medical oncology, radiation oncology) conference. 
Nason et al.

It is the policy of our ethics committee that no consent or prior ethical approval is required for a retrospective chart review.

The data was divided into 3 equal consecutive time periods for comparison purposes: Group 1 for 1995 to 2000, Group 2 for 2001 to 2006 and Group 3 for 2007 to 2012.

All statistical analyses were performed using Minitab version 16.0 (Minitab Inc., State College PA). Differences in patient characteristics between the 6 time periods were tested using Fisher's exact test and one-way analysis of variance (ANOVA). Overall and disease-specific survival was calculated using the Kaplan-Meier method. Time was calculated from date of diagnosis to date of death or to 31 December 2012 if alive at that time. The log-rank test was used to test differences in the disease-specific survival between the 6 periods. All deaths were cross-referenced with the National Cancer Registry of Ireland and the General Registry Office. A $p$ value less than 0.05 was considered statistically significant.

\section{Results}

Between 1995 and 2012, 507 patients underwent nephrectomy for RCC in our unit. Overall, rates of nephrectomies increased over the study period (Fig. 1).

There were 105 patients in Group 1 (1995-2000), 146 in Group 2 (2001-2006) and 256 in Group 3 (2007-2012). The median age was 60.1 (range: $23-88$ ). There were 198 females and 309 males. No difference in age $(p=0.275)$ or sex distribution ( $p=0.871)$ was observed between the groups. The clinico-pathological parameters are summarised in Table 1.

The median tumour size was $5.8 \mathrm{~cm}$ (range: 1.2-20) and there was no statistical reduction in size observed over time $(p=0.477)$. A total of $142(28 \%)$ RCCs were classified as pT1a, 111 (21.9\%) as pT1b, 67 (13.2\%) as pT2, 103 (20.3\%) as pT3a, $75(14.8 \%)$ as pT3b and $9(1.8 \%)$ as pT4. Organconfined (pT1a, pT1b, pT2) tumours accounted for $63.1 \%$ of the series and there was no statistical T-stage migration observed ( $p=0.213$ ). 6.5\% were Fuhrman nuclear grade $1,43.6 \%$ were grade $2,38.3 \%$ were grade 3 and $11.6 \%$ were grade 4 . There was a significant grade reduction over time $(p=0.017)$, with an increased representation of grade 1 (from $1.9 \%$ to $6.3 \%$ ) and grade 2 (from $35.2 \%$ to $55.6 \%$ ) tumours and a decrease in grade $3(51.9 \%$ to $24.6 \%)$. The histological subtypes remained consistent with time, with clear cell carcinomas being the most common (83\%), followed by papillary carcinomas $(9.3 \%)$ and chrombophobe carcinomas (5.9\%).

There was a significant difference between overall and disease-specific survival over the study period $(67.9 \%$ vs. $82.1 \%$, respectively, $p<0.001)$. The overall 1 -year, 3 -year and 5 -year survival rates were $90.5 \%, 70.7 \%$ and $57.2 \%$, respectively. The disease-specific 1 -year, 3-year, 5-year survival rates were $93.3 \%, 81.4 \%$ and $71.6 \%$, respectively (Fig. 2). There was no difference between overall 1-year survival rates $(83.8 \%, 88.4 \%, 91.1 \%$, respectively), 3-year survival rates $(72.4 \%, 78.1 \%, 81.2 \%$, respectively) and 5-year sur-

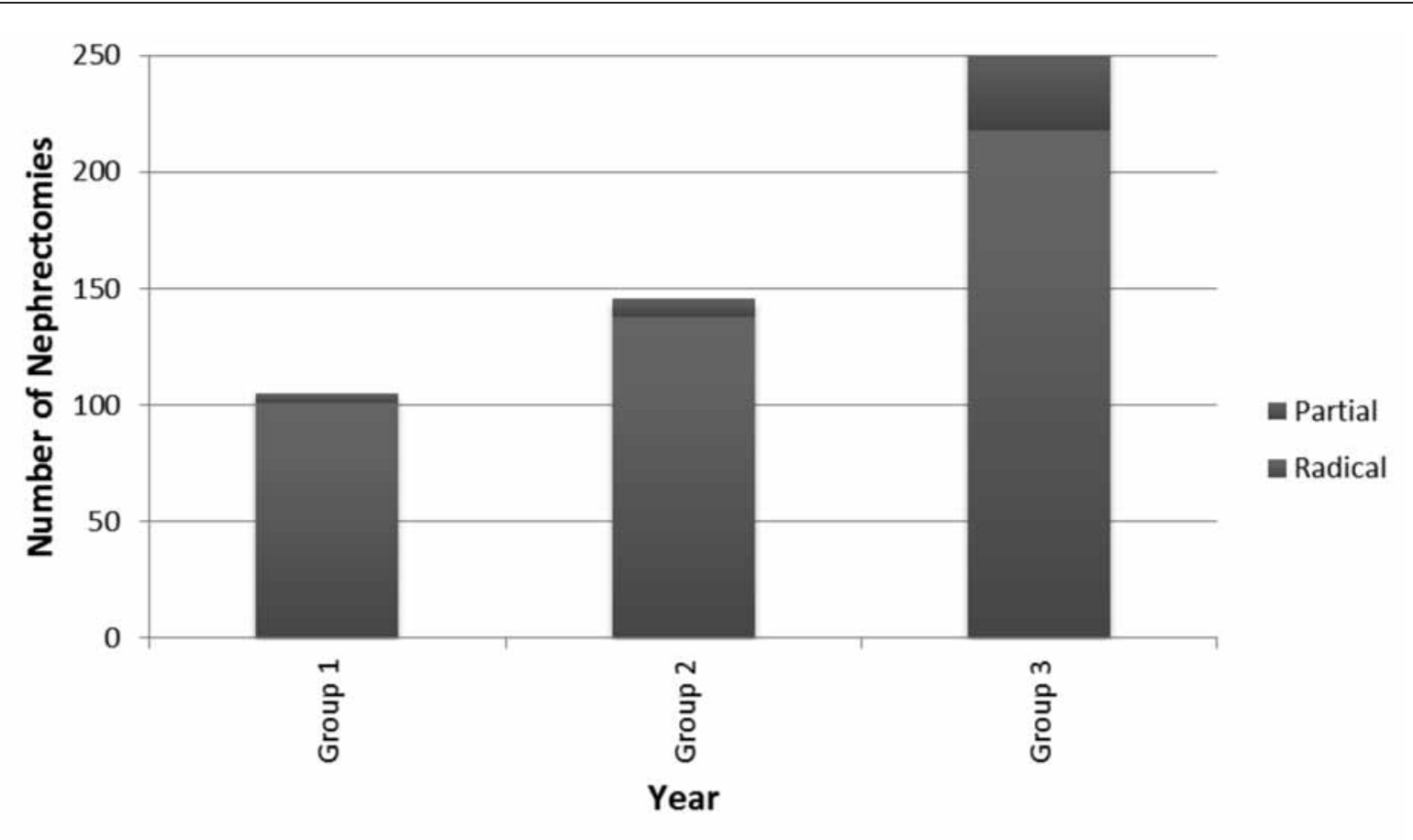

Fig. 1. Trends in the number of nephrectomies performed between 1995 and 2012. 
RCC and decreasing tumour grade

\begin{tabular}{|c|c|c|c|c|}
\hline & $\begin{array}{c}1995-2000 \\
\text { Group } 1\end{array}$ & $\begin{array}{c}2001-2006 \\
\text { Group } 2\end{array}$ & $\begin{array}{c}2007-2012 \\
\text { Group } 3\end{array}$ & Total \\
\hline Total no. & 105 & 146 & 256 & 507 \\
\hline \multicolumn{5}{|l|}{ Gender } \\
\hline Female, $\mathrm{n}(\%)$ & $36(34.3)$ & $68(46.6)$ & $94(36.7)$ & $198(39.1)$ \\
\hline Male, n (\%) & $69(65.7)$ & $78(53.4)$ & $162(63.3)$ & 309 (60.9) \\
\hline \multicolumn{5}{|l|}{ Age } \\
\hline Average Age $( \pm S D)$ & $59.7 \pm 13.7$ & $59.5 \pm 11.2$ & $59.28 \pm 11.2$ & $60 \pm 11.7$ \\
\hline \multicolumn{5}{|l|}{ Side } \\
\hline Left, n (\%) & $42(38.9)$ & $71(48.6)$ & $134(52.3)$ & $247(48.7)$ \\
\hline Right, n (\%) & $63(61.1)$ & $75(51.4)$ & $122(47.7)$ & $260(51.3)$ \\
\hline \multicolumn{5}{|l|}{ Tumour size $(\mathrm{cm})$} \\
\hline Mean $( \pm \mathrm{SD})$ & $6.56 \pm 3.48$ & $6.9 \pm 3.2$ & $6.29 \pm 3.43$ & $6.44 \pm 3.45$ \\
\hline \multicolumn{5}{|l|}{ Procedure, $n(\%)$} \\
\hline Radical & $101(96.2)$ & $138(94.5)$ & $218(85.2)$ & $457(90.1)$ \\
\hline Partial & $4(3.8)$ & $8(5.5)$ & $38(14.8)$ & $50(9.9)$ \\
\hline \multicolumn{5}{|c|}{ Pathologic T stage, $n$ (\%) } \\
\hline pT1a & $26(24.8)$ & 29 (19.9) & $87(34)$ & $142(28)$ \\
\hline $\mathrm{pT} 1 \mathrm{~b}$ & $27(25.7)$ & $31(21.2)$ & $53(20.7)$ & 111 (21.9) \\
\hline pT2 & $17(16.2)$ & $22(15.1)$ & $28(10.9)$ & $67(13.2)$ \\
\hline рT3a & $20(19)$ & $32(21.9)$ & 51 (19.9) & $103(20.3)$ \\
\hline pT3b & $13(12.4)$ & $30(20.5)$ & $32(12.5)$ & 75 (14.8) \\
\hline pT4 & $2(1.9)$ & $2(1.4)$ & $5(2)$ & $9(1.8)$ \\
\hline \multicolumn{5}{|l|}{$N$ stage, $n(\%)$} \\
\hline No & $102(97.1)$ & $143(97.9)$ & $246(96.1)$ & 491 (96.8) \\
\hline N1 & $2(1.9)$ & $3(2.1)$ & $6(2.3)$ & $11(2.2)$ \\
\hline N2 & $1(1)$ & $0(0)$ & $4(1.6)$ & $5(1)$ \\
\hline \multicolumn{5}{|l|}{ M stage, $n(\%)$} \\
\hline Mo & $105(100)$ & $144(98.6)$ & $249(97.3)$ & 498 (98.2) \\
\hline M1 & $0(0)$ & $2(1.4)$ & $7(2.7)$ & $9(1.8)$ \\
\hline \multicolumn{5}{|c|}{ Histological subtype, $n$ (\%) } \\
\hline Clear cell & $87(82.3)$ & $127(87)$ & $207(80.1)$ & $421(83)$ \\
\hline Papillary & $11(10.5)$ & $11(7.5)$ & $25(10)$ & $47(9.3)$ \\
\hline Chromophobe & $3(2.9)$ & $7(5)$ & $20(7.8)$ & $30(5.9)$ \\
\hline Eosinophillic & $3(2.9)$ & $0(0)$ & $0(0)$ & $3(0.6)$ \\
\hline Spindle cell & $1(1)$ & $1(0.7)$ & $3(1.2)$ & $5(1)$ \\
\hline Bellini ductus & $0(0)$ & $0(0)$ & $1(0.4)$ & $1(0.2)$ \\
\hline \multicolumn{5}{|l|}{ Nuclear grade, $n(\%)$} \\
\hline $\mathrm{G} 1$ & $6(5.7)$ & $13(8.9)$ & $14(5.5)$ & $33(6.5)$ \\
\hline G2 & $39(37.1)$ & $41(28.1)$ & $141(55.1)$ & $221(43.6)$ \\
\hline G3 & $48(45.7)$ & 70 (47.9) & $76(29.7)$ & $194(38.3)$ \\
\hline G4 & $12(11.4)$ & $22(15.1)$ & $25(9.8)$ & 59 (11.6) \\
\hline \multicolumn{5}{|c|}{ Tumour necrosis, $n$ (\%) } \\
\hline Yes & 35 (33.3) & 46 (31.5) & $93(36.3)$ & $174(34.3)$ \\
\hline No & $70(66.7)$ & $100(68.5)$ & $163(63.7)$ & $333(65.7)$ \\
\hline \multicolumn{5}{|l|}{ IVC invasion, $n(\%)$} \\
\hline Yes & $0(0)$ & $4(2.7)$ & $3(1.2)$ & $7(1.4)$ \\
\hline No & $105(100)$ & $142(97.3)$ & $253(98.8)$ & $500(98.6)$ \\
\hline
\end{tabular}




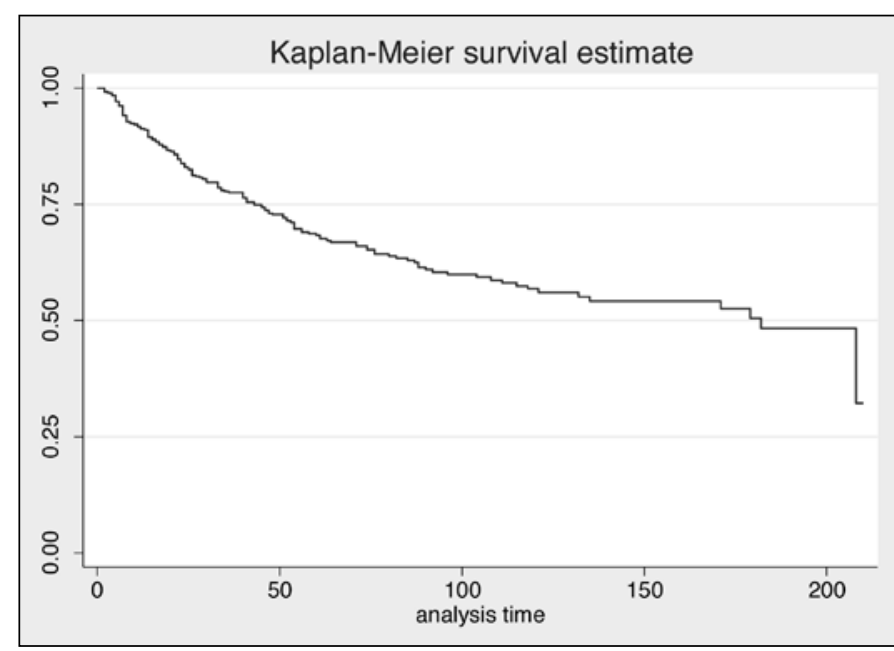

Fig. 2a. Overall survival for patients undergoing nephrectomy for renal cell carcinoma from 1995 to 2012.

vival rates $(64.8 \%, 67.1 \%, 72.1 \%$, respectively) between the 3 groups $(p=0.341)$. There was no difference between disease-specific 1 -year survival rates $(91.4 \%, 91.1 \%, 93.2 \%$, respectively), 3-year survival rates $(85.7 \%, 82.2 \%, 88.3 \%$, respectively) and 5-year survival rates $(81.9 \%, 74.7 \%$, $83.1 \%$ respectively) between groups $(p=0.081$ ) (Fig. 3 ).

Significant differences were noted in overall survival between the T-stages $(p<0.001)$, nuclear grades $(p<0.001)$ and histological subtypes ( $p=0.022)$ (Fig. 4$)$.

\section{Discussion}

In our Irish surgical series, we found an increase in the number of nephrectomies performed over the study period, with a threefold increase since 1995. Despite this, a migration towards lower T-stage tumours has not been observed and mean tumour size has remained stable $(6.44 \mathrm{~cm})$. We found

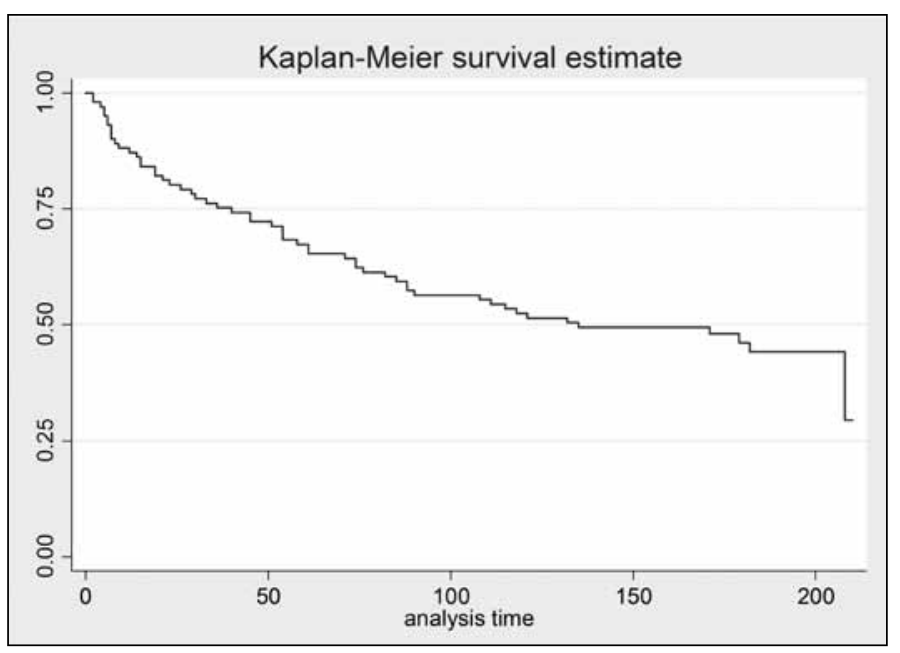

Fig. 3a. Overall survival in Group 1.

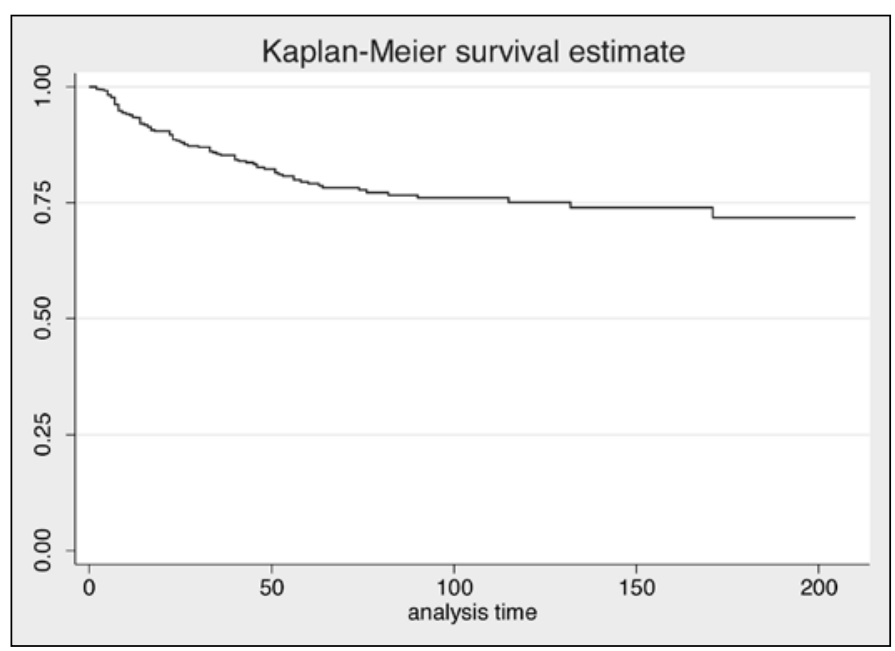

Fig. 2b. Disease-specific survival for patients undergoing nephrectomy for renal cell carcinoma from 1995 to 2012.

that $63.1 \%$ represented organ-confined tumours (pT1a, pT1b, pT2) and this has remained constant. We observed a trend towards lower nuclear (Fuhrman) grade tumours, with an increasing representation of grade 1 tumours and grade 2 tumours, and a decrease in grade 3 tumours. The cause for a decreasing tumour grade is uncertain particularly given that tumour size has remained consistent in our series. One contributing factor may be that modern imaging is detecting tumours earlier. Also, it may be a change in pathological reporting, which would need to be tested by re-grading all specimens across the 3 groups - this is not practical.

Our findings are not consistent with previous international reports. A large analysis from the United States, reviewing 205963 RCCs, demonstrated a stage migration pattern; clinical (radiological based) stage 1 RCC increased from about $43 \%$ to $57 \%$ in new patients between 1993 and 2004. A subset analysis of only surgically staged patients

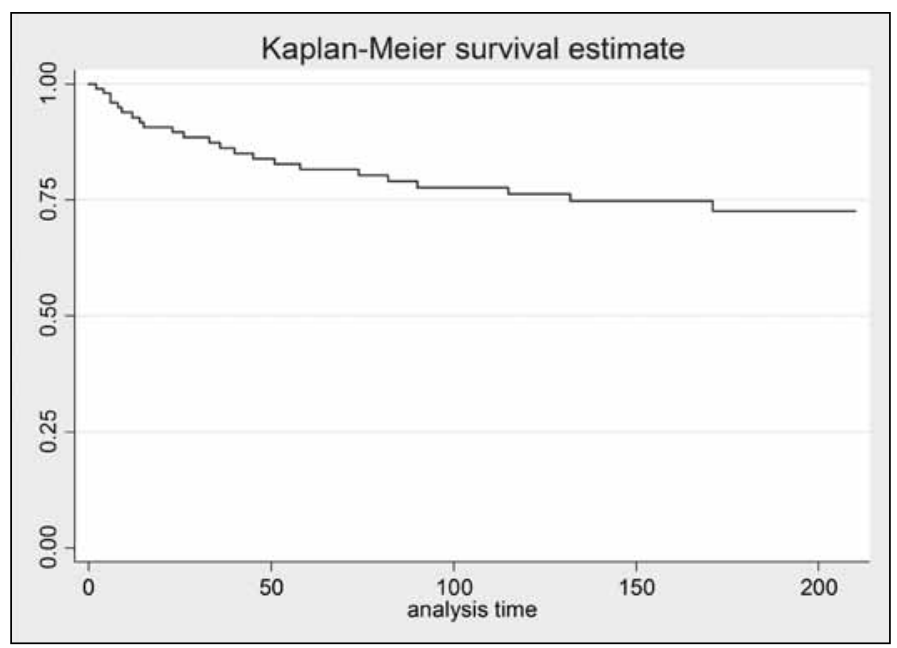

Fig. 3b. Disease specfic survival in Group 1. 


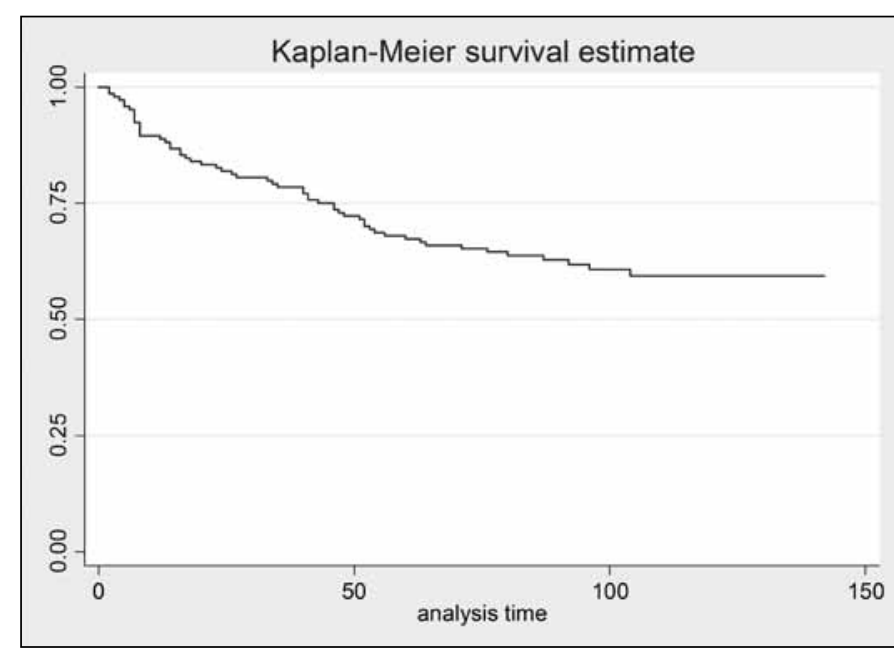

Fig. 3c. Overall survival in Group 2.

still observed an increase in pathological pT1 RCC patients from $51 \%$ to $60 \%$ between 1993 and 2004 . There was a concomitant decrease in the proportion of all other stages of disease during the same time interval. ${ }^{9}$ Pathologic and clinical staging may yield different results because tumours tend to be larger on imaging than their ultimate size when measured pathologically. ${ }^{14}$ The size of stage 1 tumours also decreased from a mean of $4.1 \mathrm{~cm}$ in 1993 to a mean of $3.6 \mathrm{~cm}$ in 2004. The mean tumour size is smaller than our series and may reflect our purely surgically treated series (stage 1 tumour mean size $4.01 \mathrm{~cm}$ ); smaller tumours undergoing surveillance were not included in our analysis.

Similarly, Pichler and colleagues reported a stage migration and decrease in tumour size in a sizable central European Caucasian series. The observed stage migration mainly consisted of an increasing number of resections of pT1a $(12.5 \%$ to $32.6 \%)$ tumours and a decreasing number of pT3a $(46.6 \%$ to $24.1 \%$ ) tumours over the 25 -year study period; there was

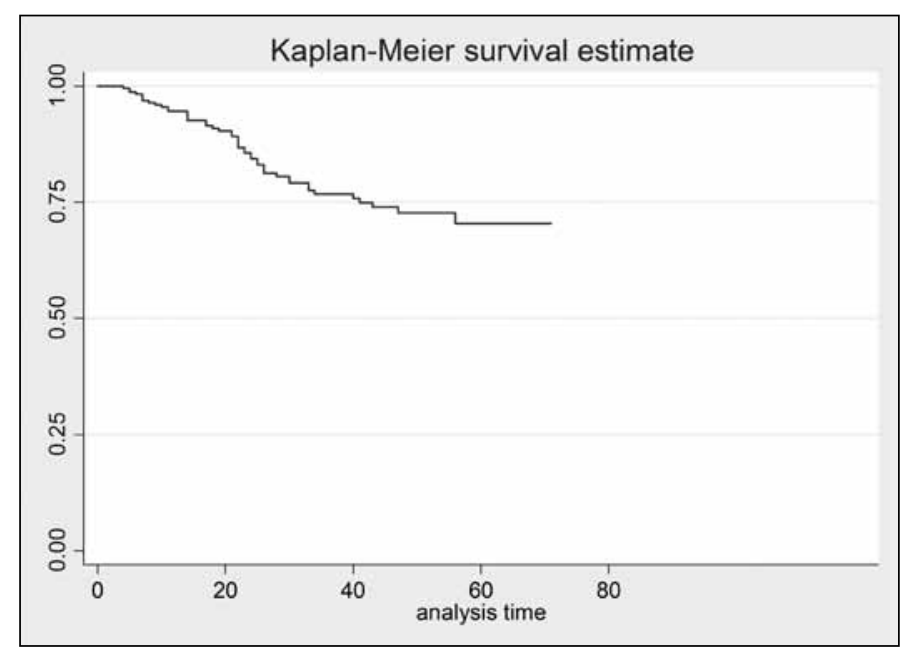

Fig. 3e. Overall survival in Group 3.

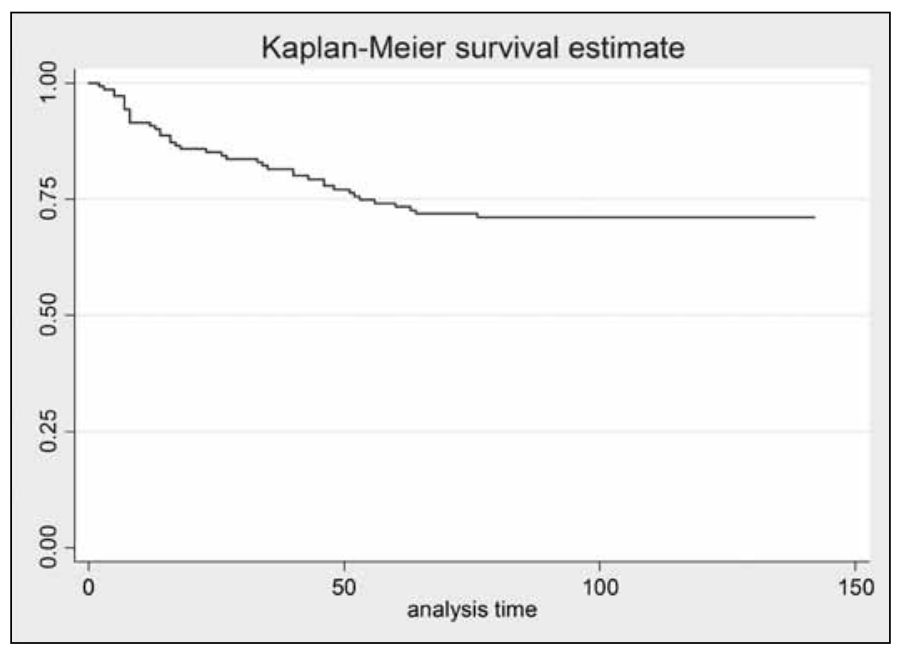

Fig. 3d. Disease specfic survival in Group 2.

also an associated decrease in mean tumour size from $6.7 \mathrm{~cm}$ to $4.8 \mathrm{~cm} .{ }^{10}$ This stage migration was accompanied by an improved metastases free 5 -year survival from $78.7 \%$ to $90.3 \%$. This survival benefit was based upon a cohort in whom no adjuvant or neo-adjuvant therapies were used. This stage migration and shift towards smaller less severe tumours were echoed in findings by Lyrdal and colleagues who assessed Scandinavians from the Swedish Cancer Registry. ${ }^{11}$ Not only did the authors assess clinically significant RCCs, they also analyzed autopsy-detected RCCs. The frequency of autopsy-detected tumours decreased from $24 \%$ to $7 \%$ indicating more incidentally diagnosed RCCs. In contrast to these 3 large studies, Doeuk and colleagues reported a similar-sized Australian series to our study population $(n=499)$. They found an upward stage shift with an increasing proportion of stage 3 tumours from $13.9 \%$ to $21.5 \%$. They also observed a trend towards more aggressive Fuhrman grade 3 tumours $17.6 \%$ to $30.8 \%$. Furthermore, despite conventional (clear

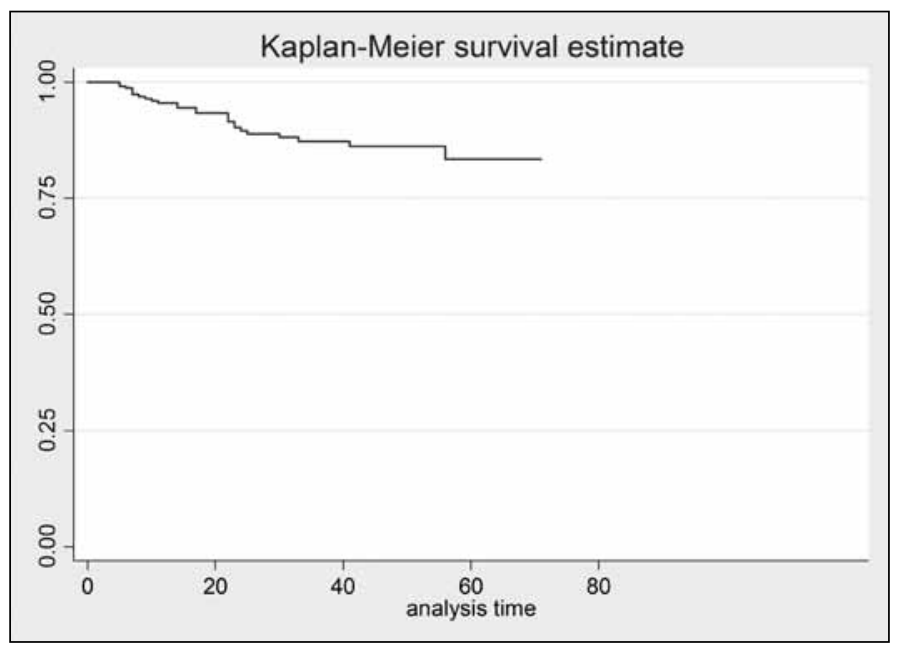

Fig. 3f. Disease specfic survival in Group 3. 
Nason et al.

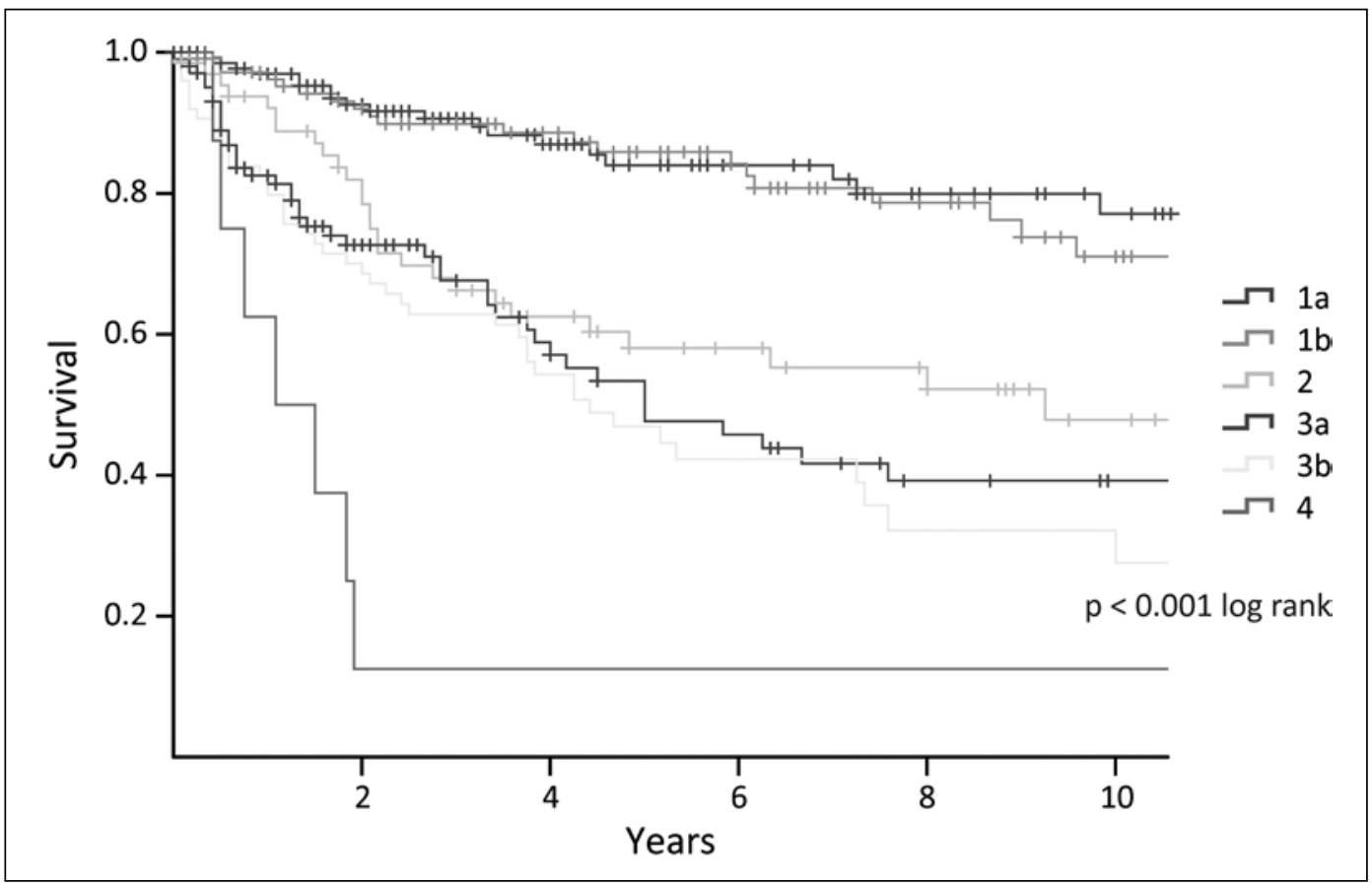

Fig. 4a. Overall survival for patients undergoing nephrectomy for renal cell carcinoma from 1995 to 2012 based on T-stage.

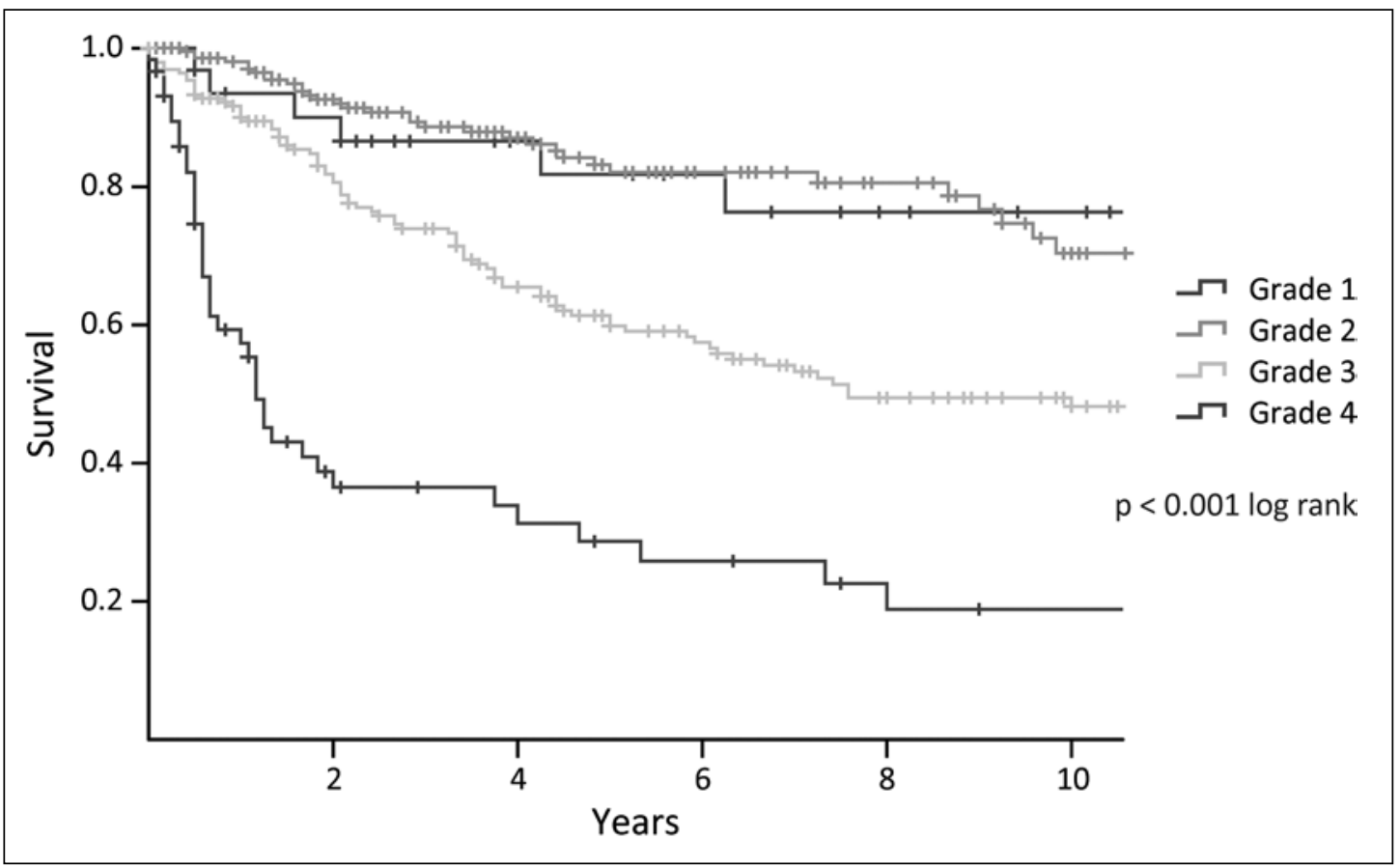

Fig. 4b. Overall survival for patients undergoing nephrectomy for renal cell carcinoma from 1995 to 2012 based on Fuhrman nuclear grade.

cell) carcinomas remaining the most common histological subtype, there was a significant increased representation of papillary carcinomas, which have a known poorer prognosis than clear cell ${ }^{15,16}$ or chrombophobe..$^{17}$
A large review of the National Cancer Database assessed the pathological characteristics of 47909 RCCs. Most (66\%) of these tumours were organ confined and the mean size was $6.49 \mathrm{~cm}$ - similar to our series. Pathological (AJCC) 


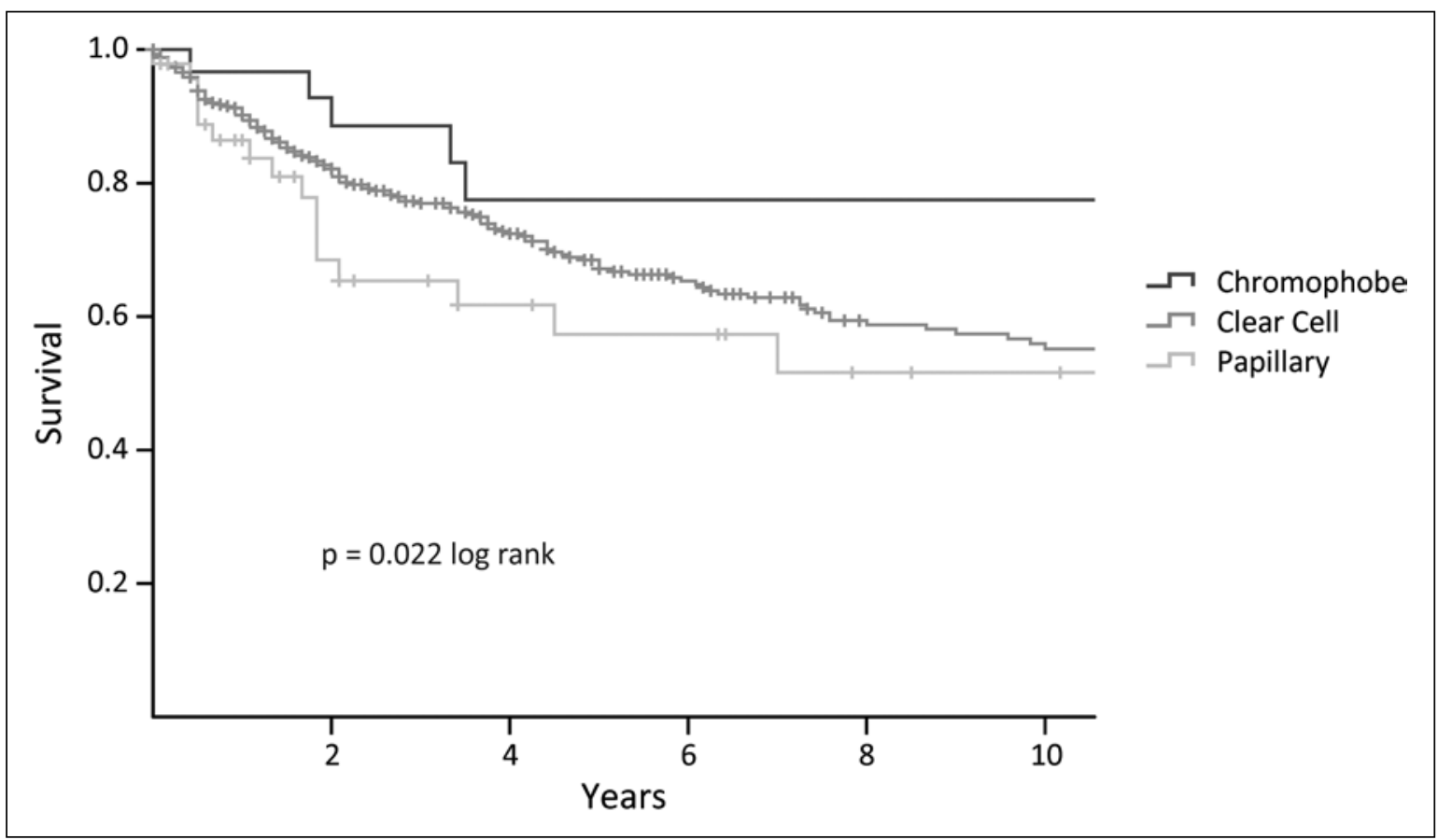

Fig. 4c. Overall survival for patients undergoing nephrectomy for renal cell carcinoma from 1995 to 2012 based on histological subtype.

stage, nuclear (Fuhrman) grade and histological subtype are key prognosticators in RCC. ${ }^{7,18}$ Our data support the significant survival advantage with regard to T-stage, nuclear grade and histological subtype. Management and risk algorithms have been validated; these algorithms incorporate these parameters for the stratification of patients with RCC (Memorial Sloan-Kettering Cancer Centre RCC nomogram, ${ }^{19,20}$ The University of Los Angeles, (UCLA) Integrated Staging System ${ }^{21}$ and the Mayo Clinic (Rochester, MN) stage, size, grade and necrosis score (SSIGN). ${ }^{22}$

The rising incidence of RCC, often accompanied by a fall in mortality, has been well-described and attributed to an increase in incidentally discovered renal tumours. ${ }^{23}$ Falebita and colleagues reported that the incidence of RCC from 1994 to 2004 rose and it was largely, but not entirely, due to an increase in incidentally diagnosed cancers. ${ }^{24}$ The improved cancer-specific survival of incidental cases has not, thus far, resulted in a decrease in overall mortality from kidney cancer, perhaps because of this lead-time bias. ${ }^{25}$

The most important limitation of our retrospective single centre study was that we only reported patients who underwent nephrectomy. As a result, we were not able to report incidence or prevalence of RCC given that this was an analysis of a purely surgical series. In our study, patients who were undergoing radiological surveillance for small suspicious renal masses and those who underwent radiological intervention may influencing factors as to why we did not observe the reported migration towards smaller lower stage tumours. Furthermore the adjustment of tumour stage to the AJCC 2010 guidelines was based on histopathological reports. The number of patients in our series with metastatic disease is quite small reflecting our survival rates; therefore, many patients with metastatic disease would not have undergone surgery and were therefore not included in this series.

\section{Conclusion}

Despite a threefold increase in the number of nephrectomies performed over the study period, the previously reported stage migration towards smaller tumours was not observed in our series. There was, however, a significant grade reduction. Tumour stage, nuclear grade and histological subtype are significant prognosticators of relative survival in RCC.

Acknowledgements: The authors would like to acknowledge the help of the National Cancer Registry of Ireland and the General Registry Office.

Competing interests: Mr. Nason, Mr. McGuire, Mr. Kelly, Mr. Murphy, Ms. Looney, Mr. Bryne, Mr. Mulvin, Mr. Galvin, Mr. Quinlan and Mr. Lennon all declare no competing financial or personal interests.

This paper has been peer-reviewed. 
Nason et al.

\section{References}

1. Chow WH, Devesa SS, Warren IL, et al. Rising incidence of renal cell cancer in the United States. JAMA 1999;281:1628-31. http://dx.doi.org/10.1001/jama.281.17.1628

2. Sweeney JP, Thornhill JA, Grainger $R$, et al. Incidentally detected renal cell carcinoma: Pathological features, survival trends and implications for treatment. $B r J$ Urol 1996;78:351-3. http://dx.doi. org/10.1046/i.1464-410X.1996.00140.x

3. Marumo K, Kanayama $\mathrm{H}$, Miyao N, et al. Prevalence of renal cell carcinoma: a nation-wide survey in Japan, 2002. Int J Urol 2007;14:479-82. http://dx.doi.org/10.1111/i.1442-2042.2007.01739.x

4. Berland LL, Silverman SG, Gore RM, et al. Managing incidental findings on abdominal CT: white paper of the ACR incidental findings committee. J Am Coll Radiol 2010;7:754-73. http://dx.doi.org/10.1016/i. jacr.2010.06.013

5. Buckens CF, Verkooijen HM, Gondrie MJ, et al. Unrequested findings on cardiac computed tomography: Looking beyond the heart. PLoS One 2012;7:e32184. http://dx.doi.org/10.1371/journal. pone. 0032184

6. Ficarra V, Righetti R, Pilloni S, et al. Prognostic factors in patients with renal cell carcinoma: retrospective analysis of 675 cases. Eur Urol 2002;41:190-8. http://dx.doi.org/10.1016/S0302-2838(01)00027-

7. Nese N, Paner GP, Mallin K, et al. Renal cell carcinoma: Assessment of key pathologic prognostic parameters and patient characteristics in 47,909 cases using the National Cancer Database. Ann Diagn Pathol 2009;13:1-8. http://dx.doi.org/10.1016/i.anndiagpath.2008.10.002

8. Gudbjartsson T, Hardarson S, Petursdottir V, et al. Histological subtyping and nuclear grading of renal cell carcinoma and their implications for survival: A retrospective nation-wide study of 629 Patients. Eur Urol 2005;48:593-600. http://dx.doi.org/10.1016/i.eururo.2005.04.016

9. Kane CJ, Mallin K, Ritchey J, et al. Renal cell cancer stage migration: Analysis of the National Cancer Data Base. Cancer 2008;113:78-83. http://dx.doi.org/10.1002/cncr.23518

10. Pichler $M$, Hutterer $G C$, Chromecki TF, et al. Renal cell carcinoma stage migration in a single European centre over 25 years: Effects on 5- and 10-year metastasis-free survival. Int Urol Nephrol 2012;44:9971004. http://dx.doi.org/10.1007/s11255-012-0165-5

11. Lyrdal $D$, Aldenborg $F$, Holmberg $E$, et al. Kidney cancer in Sweden: $A$ decrease in incidence and tumour stage, 1979 - 2001. Scand J Urol 2013;47:302-10. http://dx.doi.org/10.3109/00365599.201 2.732608

12. Ishikawa I, Honda R, Yamada Y, et al. Renal cell carcinoma detected by screening shows better patient survival than that detected following symptoms in dialysis patients. Ther Apher Dial 2004;8:468-73. http://dx.doi.org/10.1111/i.1774-9987.2004.00192.x

13. Doeuk N, Guo DY, Haddad R, et al. Renal cell carcinoma: Stage, grade and histology migration over the last 15 years in a large Australian surgical series. BJU Int 2011;107:1381-5. http://dx.doi. org/10.1111/j.1464-410X.2010.09786.x
14. Schlomer B, Figenshau RS, Yan Y, et al. How does the radiographic size of a renal mass compare with the pathologic size? Urology 2006;68:292-5. http://dx.doi.org/10.1016/i.urology.2006.03.004

15. Zucchi A, Novara G, Costantini E, et al. Prognostic factors in a large multi-institutional series of papillary renal cell carcinoma. BJU Int 2012;109:1 140-6. http://dx.doi.org/10.1111/j.1464-410X.2011.10517.x

16. Kim KH, You D, Jeong IG, et al. Type II papillary histology predicts poor outcome in patients with renal cell carcinoma and vena cava thrombus. BJU Int 2012;110:E673-8. http://dx.doi.org/10.1111/i.1464410X.2012.11498.x

17. Volpe A, Novara G, Antonelli A, et al. Chromophobe renal cell carcinoma (RCC): Oncological outcomes and prognostic factors in a large multicentre series. BJU Int 2012;110:76-83. http://dx.doi.org/10.1111/ j.1464-410X.2011.10690.x

18. Frank I, Blute ML, Leibovich BC, et al. Independent validation of the 2002 American Joint Committee on Cancer primary tumour classification for renal cell carcinoma using a large, single institution cohort. J Urol 2005;173:1889-92. http://dx.doi.org/10.1097/01.ju.0000158043.94525.d6

19. Sorbellini M, Kattan MW, Snyder ME, et al. A postoperative prognostic nomogram predicting recurrence for patients with conventional clear cell renal cell carcinoma. J Urol 2005;173:48-51. http://dx.doi. org/10.1097/01.ju.0000148261.19532.2c

20. Kattan MW, Reuter V, Motzer RJ, et al. A postoperative prognostic nomogram for renal cell carcinoma. J Urol 2001;166:63-7. http://dx.doi.org/10.1016/50022-5347(05)66077-6

21. Zisman A, Pantuck AJ, Dorey F, et al. Improved prognostication of renal cell carcinoma using an integrated system. J Clin Oncol 2001:19:1649-57.

22. Frank I, Blute ML, Cheville JC, et al. An outcome prediction model for patients with clear cell renal cell carcinoma treated with radical nephrectomy based on tumor stage, size, grade and necrosis: the SSIGN score. J Urol 2002;168:2395-400. http://dx.doi.org/10.1016/S0022-5347(05)64153-5

23. Liu S, Semenciw R, Morrison H, et al. Kidney cancer in Canada: The rapidly increasing incidence of adenocarcinoma in adults and seniors. Can J Public Health 1997;88:99-104.

24. Falebita $\mathrm{OA}$, Mancini S, Kiely E, et al. Rising incidence of renal cell carcinoma in Ireland. Int Urol Nephrol 2009;41:7-12. http://dx.doi.org/10.1007/s1 1255-008-9413-0

25. Gudbjartsson $\mathrm{T}$, Thoroddsen $A$, Petursdottir $V$, et al. Effect of incidental detection for survival of patients with renal cell carcinoma: Results of population-based study of 701 patients. Urology 2005;66:1186-91. http://dx.doi.org/10.1016/i.urology.2005.07.009

Correspondence: Mr Gregory Nason, St. Vincent's University Hospital, Dublin 4, Ireland; nasong@tcd.ie 